contributions to the geology of the rocks of the Highlands and of the glacial deposits of central Scotland, and he played a.big part in the preparation of the Scottish exhibits for the opening of the new Geological Museum in London in 1935.

\section{British Empire Cancer Campaign}

AT a recent meeting, the British Empire Cancer Campaign allocated a sum of $£ 39,000$ for the continuation of cancer research during the calendar year 1945. This sum compares with grants totalling nearly $£ 36,000$ for the present year. The principal grants are as follows : $£ 10,613$ to the Royal Cancer Hospital (Free), including the Chester Beatty Research Institute; $£ 8,000$ to the Middlesex Hospital ; $£ 3,500$ to St. Bartholomew's Hospital ; $£ 1,800$ to the London Hospital; $£ 2,743$ to Mount Vernon Hospital and the Radium Institute; $£ 850$ to St. Mark's Hospital, City Road; $£ 1,100$ to the Marie Curie Hospital; $£ 120$ to the Bristol University Cancer Research Committee; $£ 2,300$ to the Cambridge University Cancer Research Centre; $£ 1,740$ to the Oxford University Cancer Research Centre; $£ 1,125$ to Westminster Hospital; and $£ 5,165$ for the expenses of cancer research at the Glasgow Royal Cancer Hospital, University of Glasgow, Institute of Animal Genetics of the University of Edinburgh, University College, Nottingham and St. Thomas's Hospital. These grants are additional to independent expenditure on cancer research by the autonomous branches of the British Empire Cancer Campaign in Birmingham, Yorkshire, Lancashire, Cheshire, North Wales, Northumberland, Cumberland and Durham.

\section{Pest Control in French North Africa}

A RECENT publication ("Les Nouvelles Méthodes Insecticides et Les Épidémies." By Dr. A. L. Lopigre. Centre Nationale de la Recherche Scientifique, Algiers) describes what is being done to reduce losses at the ports, in the marshalling yards and in the agricultural depots in French North Africa, resulting from infestation by insects and rats. The loss of potatoes caused by the tuber moth is stated to exceed. 50 per cent within three months of harvesting, most of which loss is preventable by fumigation. Dr. A. L. Lepigre, whose pioneer work on the fumigants ethylene oxide and methyl bromide is well known, describes the fumigants and methods now in use in the eight large official stations for désinsectisation in Algiers, and the possibility of using vacuum and mobile chambers. Ethylene oxide, hydrogen cyanide and methyl bromide are recommended; but it seems that ethylene oxide is not available in Algiers at present. Chlorpicrin, once highly favoured by the French authorities, is described as being too unpleasant. A brief account of these fumigants is given, and special interest is attached to the statement that ethylene oxide is bactericidal as well as insecticidal, and as such is probably more effective than formalin or sulphur dioxide.

The need for specialists trained in fumigation practice is specially stressed. Loss of lives by typhus, and loss of foodstuffs and other commodities, still occur on a large scale, losses which can on Dr. Lepigre's showing be prevented if the organization of trained staff and equipment, which he describes, can be provided. That is true of many military and civilian bases and depots apart from the North Africanin India for example-but there is little prospect of effective action until trained practitioners are avail. able.

\section{British Rheologists' Club}

THe fourth annual general meeting of the British Rheologists' Club was held at the University, Reading, on Saturday, October 21. The retiring president, Commander C. F. Goodeve, took the chair at the business meeting. The following were elected officers for the ensuing year: President, Prof. E. N. da C. Andrade; Hon. Secretary, Dr. G. W. Scott-Blair; Hon. Treasurer, Dr. V. G. W. Harrison. The following were also elected to the Committee : Mr. R. L. Brown, Dr. C. A. Maunder Foster; Dr. E. W. J. Mardles, Dr. L. R. G. Treloar. Dr. Scott-Blair reported an increase of more than ninety in the membership figures during the past year. There had been three general meetings, of which one had taken the form of a week-end conference. This had led to closer co-operation between rheologists working in numerous fields. The Committee especially welcomed the newly established contacts with metallurgists. Very cordial relations existed with the (American) Society of Rheology, and it was hoped in the near future to make contact with Soviet rheologists through the courtesy of the Embassy of the U.S.S.R. The business meeting was followed by a discussion on "Tack" introduced by Dr. N. A. de Bruyne and Mr. R. F. Bowles.

\section{Dust Precipitation from Boiler Flue Gases}

A PAPER on this subject was read in London on November 2 before the Institution of Electrical Engineers, by John Bruce. In it the author deals particularly with the electrostatic precipitation of dust entrained by flue gases produced from the combustion of anthracite in pulverized form. The paper describes field experiments and results on a pilotscale electrostatic precipitator operating on such fiue gases, as well as the salient features of a large-scale commercial installation. Some of the operating results obtained therefrom are also discussed.

\section{Announcements}

Prof. M. N. SAHA, of the University College of Science and Technology, Calcutta, will deliver a lecture before the Physical Society on "A Physical Theory of the Solar Corona" on November 23, at 5.0 p.m. The lecture will be given in the rooms of the Royal Society, Burlington House, Piccadilly, London, W.1, and members of the Royal Astronomical Society are also invited.

THE Melbourne correspondent of The Times announces that Mr. W. Russell Grimwade, a member of the Council of the University of Melbourne, has

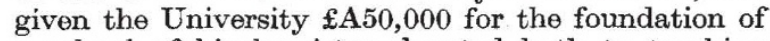
a school of biochemistry devoted both to teaching and research. Mr. Grimwade, who is chairman of the directors of Drug Houses (Australia), Ltd., manufacturing chemists and druggists, has been active in the war-time production in Australia of drugs previously imported.

From time to time correspondents have written offering to present unwanted issues of Nature to institutions or libraries. In view of the many losses sustained by French universities and libraries during the German occupation, and the difficulty in replacing such losses, readers may like to know that Prof, P. Auger, Commissariat de l'Education Nationale, 1 Carlton Gardens, London, S.W.1, is prepared to receive copies of Nature for dispatch to France. 